\title{
Defining a New 21st Century Skill-Computational Thinking: Concepts and Trends
}

\author{
Halil İbrahim Haseski ${ }^{1}$, Ulaş İlic ${ }^{2}$ \& Ufuk Tuğtekin ${ }^{3}$ \\ ${ }^{1}$ Department of Computer Education and Instructional Technology, Faculty of Education, Celal Bayar \\ University, Manisa, Turkey \\ ${ }^{2}$ Department of Computer Education and Instructional Technology, Faculty of Education, Pamukkale University, \\ Denizli, Turkey \\ ${ }^{3}$ Department of Computer Education and Instructional Technology, Faculty of Education, Anadolu University, \\ Eskişehir, Turkey
}

Correspondence: Halil İbrahim Haseski, Department of Computer Education and Instructional Technology, Faculty of Education, Celal Bayar University, Manisa, Turkey. E-mail: halil.haseski@cbu.edu.tr

Received: November 13, 2017

doi:10.5539/ies.v11n4p29
Accepted: December 15, 2017 Online Published: March 28, 2018

URL: https://doi.org/10.5539/ies.v11n4p29

\begin{abstract}
Computational Thinking is a skill that guides the 21th century individual in the problems experienced during daily life and it has an ever-increasing significance. Multifarious definitions were attempted to explain the concept of Computational Thinking. However, it was determined that there was no consensus on this matter in the literature and several different concepts were mentioned in the definitions found in the literature. It was considered that this fact made it difficult to understand the concept of Computational Thinking. To establish a more comprehensive approach, the present study aimed to identify the concepts that are included in the Computational Thinking definitions that were presented in previous studies. It also aimed to reveal trends in the identified concepts throughout the years. As a result of the search, a total of 59 definitions were identified and a content analysis was conducted on these definitions. Analysis results demonstrated that Computational Thinking was defined based on several concepts such as problem solving, technology, thinking, individual and social qualities. Furthermore, it was determined that statements on thinking were prominent before 2006, and today, emphasis on problem solving and technology became more significant. It was considered that the present study would contribute to a better understanding of the Computational Thinking concept. At the end of the study, certain suggestions were presented for further research.
\end{abstract}

Keywords: computational thinking, definitions, concepts, trend

\section{Introduction}

The rising prevalence of computers in the 1980s since the development of user-friendly interfaces, and their infiltration into different areas of daily life increased the interaction between humans and computers. In this process, the operational methods of computers began to affect and guide individuals' thinking processes. Parallel to these developments, the concept of Computational Thinking (CT) was introduced in a study by Wing (2006) and became quite popular. Today, CT is considered as a skill that 21 st-century individuals should acquire and utilize in solving the problems that are encountered in life efficiently. The International Society for Technology in Education (ISTE) indicated that algorithmic and arithmetic thinking had an influence on the CT concept and identified CT as one of the learner characteristics in the 21 st century (ISTE, 2011). Especially during the last decade, various studies were conducted on CT to define the concept. In this context, diSessa (2001) stated that $\mathrm{CT}$ is a term that reflects the methods and perspectives of computer sciences that could be utilized by individuals. Wing (2006) emphasized the significance of CT in problem solving, system design, and understanding the human behavior using the fundamental concepts of computer science. According to Guzdial (2008), CT is a general problem-solving process that was based on abstraction, analysis, automation, and modeling. The National Research Council (NRC) (2010) identified CT as a set of ideas, strategies, and mental habits that could be used in problem solving. Carnegie Mellon (2014) referred to CT as the use of computers to support thinking and problem solving activities. Williamson (2015) argued that CT was an emerging form of political approach that assumes that several public and social problems could be solved with digital innovations. 
Kafai (2016) stated that CT is a social practice.

Multifarious definitions of $\mathrm{CT}$ were attempted in the literature to emphasize different dimensions of the concept; however, the authors were not able to reach a consensus. It was considered that the abovementioned lack of consensus prevented the comprehension of the concept and its prevalence as a skill among the public. In this context, various literature reviews were conducted to make CT more comprehensible (Demir \& Seferoğlu, 2017; Özçınar, 2017). However, in these studies, it was determined that the concept was discussed at the level of a few basic definitions and analyzed on a national basis or only descriptive statistics were used based on the study title, summary and keywords. To create a better understanding on the subject, the present study aimed to reveal the concepts that were included in the definitions developed for CT and trends in the identified concepts throughout the years.

\section{Method}

\subsection{Research Model}

In the present study, a comprehensive search was conducted on electronic databases with keywords determined based on the study objective and to access the publications on CT. The accessed publications were examined with the "Computational Thinking Definition Form" that was developed by the authors based on the document analysis technique. The data were analyzed with content analysis method. Content analysis is a preferred method to compare, classify and associate the data obtained in a study (Fraenkel \& Wallen, 2000; Weber, 1990).

\subsection{Search Strategies}

The search process was conducted in two stages in the study; it was initially conducted on Web of Science (WoS) and ERIC databases and then, using Google search engine to access the resources cited in the publications found in the abovementioned databases. The use of data on CT that were obtained from different databases was useful to clarify the trends in definitions. Thus, the study aimed to access diverse resources. WoS and ERIC databases were chosen as the primary source in the search process since the databases in question were prominent databases in the field of educational technologies and the CT publications found in these databases were scientific articles. In the WoS database, the search was conducted with the keyword "computational thinking". Furthermore, the articles that contained "computational" and "thinking" keywords in the title were also included in the study. Similarly, the ERIC database was searched using the keywords "computational" and "thinking". In case the full text of the publication was not obtained due to open-access limitations, the web page of the journal where the publication was published was utilized. Furthermore, communications with related authors were established. The keyword searches were conducted on December 10-11, 2016, and a total of 271 publications were accessed including 101 articles in WoS and 170 in ERIC databases published before 2016. Accessed publications were reconsidered based on whether the title, abstract, and full manuscript were present. Thus, it was determined whether these publications were eligible for inclusion in the present study. Based on the abovementioned criteria the number of articles was reduced to 96 . The article manuscripts were examined for different and original CT definitions. The analyses resulted in 38 articles where CT was defined either directly or by reference to other resources. Among the publications, a separate search was conducted to access the secondary resources cited in CT definitions provided by the primary studies.

In the second search phase of the study, secondary sources that included CT definitions were searched with the Google search engine. In this phase, a total of 21 resources were identified that originally defined CT including 9 books, 5 proceedings, 4 educational institution websites, 2 university websites and 1 statistical institution website. At the end of the two-phase search process, a total of 59 different publications that included CT definitions were identified.

\subsection{Inclusion/Exclusion Criteria}

In the present study, inclusion-exclusion criteria were determined as is customary in systematic literature reviews. These criteria were as follows:

1) The study should be scientific,

2) The study should be published before 2016 ,

3) Full text of the study should be available,

4) The study should be about CT,

5) The study should include a direct definition of CT.

The first criterion aimed to access high quality and large number of publications in different types. Thus, 
resources such as scientific articles, proceedings, books and educational institution websites were included in the study. The aim of the second criterion was to cover the studies conducted on the topic in a wide time frame. Although the study by Wing (2006) was accepted as the milestone on CT research in the literature, publications on the subject of CT that were published before 2006 and included original definitions were also included in the study. The studies published in 2017 were not included in the analysis. Although certain journals were already published in 2017 when the present study was conducted, they were excluded from the study since their numbers were limited and the authors did not want these articles to affect the annual trends before the year was over. Another criterion was the availability of the full text of the manuscript. The papers where only the abstract was available were excluded since this fact would limit the analysis process. Topic selection was also among the inclusion / exclusion criteria. Several studies in different fields were accessed as a result of the conducted search. Studies on mathematical computational theories and computational models that were outside the scope of the present analysis were excluded from the analysis. The final criterion was to include a direct definition for CT. Due to its popularity, several studies were conducted on CT in recent years. Certain studies included original definitions for CT. On the other hand, in most studies, CT definitions that were published in previous studies were cited and original definitions that could contribute to the present study were not included. Thus, based on the final criterion, these publications were excluded and only studies that contained original CT definitions were included in the analysis. The original publications cited by the primary resources for CT definitions were accessed and these secondary resources were included in the analysis conducted in the present study. Studies that could not meet any of the above criteria were not included in the analysis.

\subsection{Data Collection Instrument}

The data was collected with the "Computational Thinking Definition Form (CTDF)" developed by the authors. This form also aimed to ensure the validity and reliability of the study. Validity is the present and unbiased observation of the investigated phenomenon (Kirk \& Miller, 1986), and reliability is considered as a reproducibility of research findings (Merriam \& Tisdell, 2015). CTDF was developed based on the study objective and previous content analysis studies conducted on educational technologies (Akbulut \& Cardak, 2012; Göktas et al., 2012; Kucuk, Aydemir, Yildirim, Arpacik, \& Goktas, 2013; Shih, Feng \& Tsai, 2008). Expert opinion was obtained from 3 measurement and assessment experts to establish the form validity and the form was finalized based on the obtained views. The abovementioned form included open-ended descriptive questions about the paper such as author name, year of publication, title, the title of the journal where the paper was published, and the item titled "What is the definition of Computational Thinking in the examined paper?" designed to determine the definitions included in the paper.

\subsection{Data Analysis}

Accessed articles were examined by the researchers using CTDF and 59 different CT definitions were determined. Content analysis was conducted on these definitions based on the concepts found in the definition content. Thus, the titles in the developed CTDF were initially entered in a spreadsheet and the properties of the titles of the publications that were included in the study were entered as data in the related columns. Descriptive statistics analysis was conducted on the said data based on the research questions. Descriptive statistics was preferred since it provides the researcher the opportunity to sort and summarize the study data (Lomax \& Hahs-Vaughn, 2012). Furthermore, relevant statistics were utilized to determine the annual trends. Data analysis process was conducted by a faculty member and $2 \mathrm{PhD}$ candidates who previously published papers on $\mathrm{CT}$. In this process, the two authors examined all the publications and the inter-coder consistency coefficients were calculated. As a result of the review, it was determined that the inter-rater agreement between coders was $\kappa=.83$. This value was considered adequate (Landis \& Koch, 1977; Viera \& Garrett, 2005). As a supervisor, the faculty member assumed the leadership role and ensured the administration of the process.

\subsection{Limitations}

One of the limitations in literature review is the inability to cover the whole literature (Van der Kleij, Feskens, \& Eggen, 2015). Another limitation of the present study is the use of only WoS and ERIC databases due to their significance in the field of study. Furthermore, search results were limited to studies published until 2016. In addition, the form used for the evaluation of definitions was another limitation of the present study.

\section{Results}

The types and the distribution of publications that included CT definitions were examined and the results are presented in Table 1. 
Table 1. The types and the annual distribution of publications that included CT definitions

\begin{tabular}{lccccc}
\hline Publication Type & Before 2000 & 2000-2005 & 2006-2010 & 2011-2016 & Total \\
\hline Article & 1 & 0 & 12 & 25 & 38 \\
Book & 0 & 1 & 4 & 4 & 9 \\
Proceeding & 0 & 1 & 1 & 3 & 5 \\
Educational institution website & 0 & 0 & 0 & 4 & 4 \\
University website & 0 & 0 & 0 & 2 & 2 \\
Statistics institution website* & 0 & 0 & 1 & 0 & 1 \\
Total & 1 & 2 & 18 & 38 & 59 \\
\hline
\end{tabular}

*National Center for Educational Statistics.

As observed in Table 1, it was understood that CT was defined in various years. It was observed that the number of definitions increased with the time. While publications that included CT definitions were in limited to a few articles and proceedings that were published before 2006, it was determined that the number of publications and diversity in publication type increased since 2006. Especially after 2011, it was interesting to observe that original definitions were also included in educational institution websites.

Table 2. Annual distribution of the concepts used in CT definitions based on the themes

\begin{tabular}{|c|c|c|c|c|c|c|}
\hline Themes and Sub-Themes & Before 2000 & $2000-2005$ & $2006-2010$ & 2011-2016 & Total & References \\
\hline 1. Problem Solving & 5 & 3 & 51 & 62 & 121 & \\
\hline 1.1. Problem Solving System & 1 & 2 & 5 & 17 & 25 & $\begin{array}{l}\text { (Brennan \& Resnick, 2012; } \\
\text { Carnegie Mellon, 2014; Chang, } \\
\text { 2014; Chen, 2009; ISTE \& CSTA, } \\
\text { 2011; diSessa, 2001; Furber, 2012; } \\
\text { Grover \& Pea, 2013; Jacobson \& } \\
\text { Wilensky, 2006; Jenkins, 2015; } \\
\text { Kafai, 2016; Lu \& Fletscher, 2009; } \\
\text { Papert, 1996; Park \& Jeon, 2015; } \\
\text { Sneider, Stephenson, Schafer \& } \\
\text { Flick, 2014; Sullivan \& Heffernan, } \\
\text { 2016; Voogt et al., 2015; Whitman } \\
\text { \& Witherspoon, 2003; Williamson, } \\
\text { 2016; Wing, 2011; Yadav et al., } \\
\text { 2014) }\end{array}$ \\
\hline \multirow[t]{2}{*}{$\begin{array}{l}\text { 1.2. Determination of } \\
\text { operational steps by } \\
\text { abstraction }\end{array}$} & \multirow[t]{2}{*}{2} & \multirow[t]{2}{*}{0} & \multirow[t]{2}{*}{7} & \multirow[t]{2}{*}{14} & \multirow[t]{2}{*}{23} & $\begin{array}{l}\text { (Barr, Harrison \& Conery, 2011; } \\
\text { Basawapatna et al., 2011; Berland } \\
\text { \& Wilensky, 2015; Bers, 2010; } \\
\text { ISTE \& CSTA, 2011; CSTA, 2011; } \\
\text { Denning, 2012; Furber, 2012; } \\
\text { Guzdial, 2008; Kafai, 2016; } \\
\text { Kilpeläinen, 2010; Lu \& Fletscher, } \\
\text { 2009; NAACE, 2014; Papert, 1996; }\end{array}$ \\
\hline & & & & & & $\begin{array}{l}\text { Snapp \& Neumann, 2015; } \\
\text { Williamson, 2015; Williamson, } \\
2016)\end{array}$ \\
\hline
\end{tabular}


1.3. Analysis of the problem 1 0 9 10 20
1

0

9

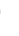

9

(Barr \& Stephenson, 2011; Barr, Harrison \& Conery, 2011; Basawapatna et al., 2011; Berland \& Wilensky, 2015; Bers, 2010; ISTE \& CSTA, 2011; CSTA, 2011; Furber, 2012; Grover \& Pea, 2013; Guzdial, 2008; Kilpeläinen, 2010; Lu \& Fletscher, 2009; National Research Council, 2012; Papert, 1996; Park \& Jeon, 2015; Wilensky \& Reisman, 2006; Williamson, 2016; Wing, 2006)

(Barr, Harrison \& Conery, 2011; Berland \& Wilensky, 2015; Bers, 2010; Guzdial, 2008; Kafai \& Burke, 2014; Kilpeläinen, 2010; Papert, 1996; National Research Council, 2010; Sengupta et al., 2013; Williamson, 2016)

(Barr \& Stephenson, 2011; Kafai \& Burke, 2014; Kilpeläinen, 2010; Lu \& Fletscher, 2009; National 1.5. Finding the possible solutions

0

0

6

6

12 Research Council, 2010; National Research Council, 2012; Sengupta et al., 2013; Sullivan \& Heffernan, 2016; Wilensky \& Reisman, 2006; Wing, 2006)

(Barr, Harrison \& Conery, 2011;

$\begin{aligned} & \text { 1.6. Finding the most } \\ & \text { adequate solution and }\end{aligned}$
implementation

Berland \& Wilensky, 2015; CSTA, 2011; Guzdial, 2008; Lu \& Fletscher, 2009; Williamson, 2016) (Berland \& Wilensky, 2015; Chen, 1.7. Organizing the resources and operational steps

0

1

4

1

6 2009; Guzdial, 2008; Whitman \& Witherspoon, 2003; Williamson, 2016)

(Barr, Harrison \& Conery, 2011; Basawapatna et al., 2011; Berland \& Wilensky, 2015; Guzdial, 2008; Williamson, 2016)

\begin{tabular}{llllll} 
1.8. Transferring the solution & 0 & 0 & 2 & 3 & 5 \\
\hline 2. Technology & 1 & 1 & 22 & 29 & 53 \\
\hline
\end{tabular}

(Barr \& Stephenson, 2011; Bundy, 2007; CSTA, 2011; Denning \& Freeman, 2009; Denning, 2012; Grover \& Pea, 2013; Guzdial, 2008; Jacobson \& Wilensky, 2006;

2.1. IT knowledge and utilization

1

0

11

12 Settle, 2011; National Research Council, 2012; Papert, 1996; Snapp \& Neumann, 2015; Williamson, 2016; Wing, 2006; Wolz et al., 2011; Yadav et al., 2014)

(Aho, 2012; Basawapatna et al.,

0

9

4

13 2011; Denning, 2012; Kafai, 2016; Lu \& Fletscher, 2009; Wing, 2008) 


\begin{tabular}{|c|c|c|c|c|c|c|}
\hline 2.3. Data processing & 0 & 1 & 1 & 6 & 8 & $\begin{array}{l}\text { (Aho, 2012; Carnegie Mellon, } \\
\text { 2014; ISTE \& CSTA, 2011; CSTA, } \\
\text { 2011; diSessa, 2001; Jenkins, 2015; } \\
\text { Kilpeläinen, 2010) }\end{array}$ \\
\hline 2.4. Computer science & 0 & 0 & 1 & 5 & 6 & $\begin{array}{l}\text { (Angeli et al., 2016; Williamson, } \\
\text { 2015; Evia, Sharp \& } \\
\text { Pérez-Quiñones, 2015; Kafai \& } \\
\text { Burke, 2013; National Research } \\
\text { Council, 2012; Wing, 2008) }\end{array}$ \\
\hline $\begin{array}{ll}2.5 . & \text { Technology-based } \\
\text { media } & \\
\end{array}$ & 0 & 0 & 0 & 2 & 2 & $\begin{array}{l}\text { (Sneider, Stephenson, Schafer \& } \\
\text { Flick, 2014) }\end{array}$ \\
\hline 3. Thinking & 3 & 6 & 9 & 17 & 35 & \\
\hline 3.1. Way of thinking & 3 & 6 & 8 & 14 & 31 & $\begin{array}{l}\text { (Basawapatna et al., 2011; Chang, } \\
\text { 2014; Chen, 2009; Computing at } \\
\text { School, 2014; diSessa, 2001; } \\
\text { Guzdial, 2008; Hayles, 2012; } \\
\text { Jenkins, 2015; Kim, Han \& Kim, } \\
\text { 2009; Lu \& Fletscher, 2009; Papert, } \\
\text { 1996; Park \& Jeon, 2015; Snapp \& } \\
\text { Neumann, 2015; Voogt et al., 2015; } \\
\text { Whitman \& Witherspoon, 2003; } \\
\text { Williamson, 2015; Williamson, } \\
\text { 2016; Wing, 2006) }\end{array}$ \\
\hline $\begin{array}{l}\text { 3.2. Structural elements of } \\
\text { thinking }\end{array}$ & 0 & 0 & 1 & 3 & 4 & $\begin{array}{l}\text { (Basawapatna et al., 2011; } \\
\text { Carnegie Mellon, 2014; Kafai \& } \\
\text { Burke, 2013; Wilensky \& Reisman, } \\
\text { 2006) }\end{array}$ \\
\hline 4. Personal Features & 1 & 2 & 4 & 9 & 16 & \\
\hline 4.1. Personal skills & 1 & 0 & 4 & 6 & 11 & $\begin{array}{l}\text { (DeSchryver \& Yadav, 2015; } \\
\text { Jacobson \& Wilensky, 2006; Kafai } \\
\text { \& Burke, 2014; Lu \& Fletscher, } \\
\text { 2009; Miller \& Settle, 2011; } \\
\text { National Research Council., 2010; } \\
\text { Papert, 1996; Sengupta et al., 2013; } \\
\text { Sneider et al., 2014; Voogt et al., } \\
\text { 2015) }\end{array}$ \\
\hline 4.2. Cognitive features & 0 & 2 & 0 & 2 & 4 & $\begin{array}{l}\text { (diSessa, 2001; Furber, 2012; Park } \\
\text { \& Jeon, 2015) }\end{array}$ \\
\hline 4.3. Perspective & 0 & 0 & 0 & 1 & 1 & (Snapp \& Neumann, 2015) \\
\hline 5. Operational Features & 1 & 2 & 3 & 6 & 12 & \\
\hline 5.1. Operational quality & 0 & 0 & 1 & 4 & 5 & $\begin{array}{l}\text { (ISTE \& CSTA, 2011; Lu \& } \\
\text { Fletscher, 2009; Sullivan } \quad \& \\
\text { Heffernan, 2016) }\end{array}$ \\
\hline 5.2. Design & 1 & 1 & 1 & 2 & 5 & $\begin{array}{l}\text { diSessa, 2001; Jacobson \& } \\
\text { Wilensky, 2006; } \quad \text { Kafai, 2016; } \\
\text { Papert, 1996; Yadav et al., 2014) }\end{array}$ \\
\hline $\begin{array}{l}\text { 5.3. Producing new } \\
\text { information }\end{array}$ & 0 & 0 & 1 & 0 & 1 & (Jacobson \& Wilensky, 2006) \\
\hline 5.4. Assessment & 0 & 1 & 0 & 0 & 1 & (diSessa, 2001) \\
\hline
\end{tabular}




\begin{tabular}{|c|c|c|c|c|c|c|}
\hline 6. General Quality & 0 & 0 & 5 & 5 & 10 & $\begin{array}{l}\text { (Brennan \& Resnick, 2012; } \\
\text { Carnegie Mellon, 2014; Chang, } \\
\text { 2014; DeSchryver \& Yadav, 2015; } \\
\text { Evia, Sharp, \& Pérez-Quiñones, } \\
\text { 2015; Jacobson \& Wilensky, 2006; } \\
\text { Lu \& Fletscher, 2009; National } \\
\text { Research Council, 2010; Wing, } \\
\text { 2006; Wing, 2008) }\end{array}$ \\
\hline 7. Social Features & 1 & 1 & 4 & 3 & 9 & \\
\hline 7.1. Environmental approach & 1 & 1 & 2 & 1 & 5 & $\begin{array}{l}\text { (Denning \& Freeman, 2009; } \\
\text { diSessa, 2001; Papert, 1996; Yadav } \\
\text { et al., 2014) }\end{array}$ \\
\hline 7.2. Social approach & 0 & 0 & 2 & 1 & 3 & $\begin{array}{l}\text { (Bundy, 2007; Jacobson \& } \\
\text { Wilensky, 2006; Kostadinov, 2013) }\end{array}$ \\
\hline 7.3. Political approach & 0 & 0 & 0 & 1 & 1 & (Wing, 2011) \\
\hline Total & 12 & 15 & 98 & 131 & 256 & \\
\hline
\end{tabular}

As observed in Table 2, CT was defined mostly within the context of problem solving, technology and thinking. Conversely, it was observed that personal, operational specifications and general qualities were less mentioned in CT definitions. It is noteworthy that the social dimension was expressed even less in the definitions of CT. Furthermore, the concepts of systematic problem solving, abstraction, analysis of the problem were stated more, while organizing the resources and operational steps and solution transfer were the least stated phenomena in CT specifications. In addition, in the context of technology, IT knowledge and use was the most expressed concept, while technology-based approaches were the least emphasized in the definitions. Additionally, in the definitions expressed within the scope of thinking, the structural elements of thinking and in the context of personal specifications, cognitive features and perspective were the least emphasized concepts. On the other hand, in the same context, it was found that specifications on thinking and personal skills were predominant. It was also noteworthy that in the scope of the functional features of CT, quality and design were the most specified concepts, while producing new information and evaluation dimensions were the least expressed concepts.

As seen in Table 2, it was identified that the frequency of CT definitions in the literature increased in time. However, it was determined that the definitions were relatively few before 2006, and they increased rapidly after 2006. In the pre-2006 period, the specifications of thinking and problem solving were prominent in the definitions. It was determined that CT was predominantly defined within the context of problem solving and technology after 2006.

It was determined that the frequencies of the codes tend to increase in general in time as observed in Table 2. In the definitions published before 2006, it was observed that the emphasis was on thinking specifications. Between 2006 and 2010, the IT knowledge and utilization became prominent in CT definitions. It was observed that the emphasis on technology was introduced during the same period. Between 2011 and 2016, it was observed that the scope of the concepts adopted in the definitions expanded. In the definitions published during this period, it was determined that the emphasis on problem-solving system was relatively prominent. Conversely, it was determined that the transfer of solution, the structural elements of thinking, the evaluation and social specifications became prominent only after 2006. Since 2011, although the frequency of the definitions was relatively lower, it was identified that definitions were made in the context of technology-based media and politics.

\section{Discussion}

The definition of concepts, phenomena or events is crucial for their comprehension and in the determination of the limits of the topic. Thus, it is important to define CT, which increasingly becomes a popular topic, despite the lack of an essential consensus on the topic (Guzdial, 2008; Selby \& Woollard, 2014). It can be stated that CT is a social consensus skill that enables individuals to make active and systematic decisions using the information and communications technologies (ICT) and collaborative approaches in real-life situations, and thus reaching the most ideal and ethical decisions and contribute to their environment, to self-discovery and to become satisfied individuals with self-esteem. Despite the fact that the definitions of CT in literature addressed different aspects of the topic, they demonstrated a stable quantitative increase in time. In this process, especially since 2006, the number of definitions on the topic increased and the publications that included the said definitions diversified. It 
is considered that this was due to the effects of the study by Wing (2006) that introduced the term. Particularly after 2011, the presence of the concept of CT on the web sites of universities and education institutions indicated the increasing significance of the topic in the field of education during recent years. The trend of increase over time was parallel to the popularization of the topic as it attracted the interest of both the researchers and practitioners (Selby, 2014).

In the definitions found in the literature, it was observed that problem solving, and technological specifications were predominant. Furthermore, it was determined that the specifications related to thinking were relatively less common. Furthermore, personal specifications, specifications on operating characteristics, general quality specifications and social specifications were mentioned less frequently. It was considered that the prevalence of problem solving specifications in definitions was due to the fact that CT was based on problem solving (Grover \& Pea, 2013; ISTE \& CSTA, 2011; Kafai, 2016; Papert, 1996; Wing, 2011). It was observed that problem solving specifications were generally in line with the practical operational steps included in the operational definition of the CT by ISTE \& CSTA (2011). On the other hand, it was observed that the least emphasized points on problem solving were the organization of the resources and operational steps and solution transfer. This was not consistent with the paradigm that the said concepts were important and critical steps in the functioning of the CT skills (Denning, 2003, ISTE \& CSTA, 2011). This disadvantage could be resolved by developing new definitions that would include the abovementioned concepts in future studies.

The emphasis on technology in definitions was due to the perception of ICT as a significant problem solving instrument with communication facilities and access to information it provides (Kim, Han, \& Kim, 2009; Sneider, Stephenson, Schafer, \& Flick, 2014). Furthermore, the concept of ICT knowledge and use was also prominent under the same theme. This concept was followed by the specifications of programming processes, data processing and computer science. It was considered that this was due to the perception that CT was associated with computer sciences (Israel, Pearson, Tapia, Wherfel, \& Reese, 2015; B. Kim, T. Kim, \& J. Kim, 2013; Pellas \& Peroutseas, 2016), although it was stated in the literature that CT is a skill for all, not only for those who are computer science professionals (Willamon, 2016; Wing, Henderson, Hazzan, \& Cortina, 2005). This finding was consistent with Özcınar's (2017) claim that CT studies were predominantly published in computer science resources. It was determined that the least emphasized concept in technological specifications was technology-based learning and work settings. It was considered that this was due to the fact that it is necessary to define CT based on educational technologies and it was not sufficiently scrutinized in relation to the professional life. This finding was consistent with the results of previous literature reviews (Özçınar, 2017). Future studies should investigate $\mathrm{CT}$ in the context of educational technologies, investigate its adaptation and use in professional life, and related concepts should be included in future definitions.

It was observed that thinking specifications were not sufficiently emphasized in the examined definitions. Hence, it was stated that $\mathrm{CT}$ included different thinking systems such as analytical thinking, mathematical thinking, engineering thinking, scientific thinking and algorithmic thinking (Basawapatna et al., 2011; Chen, 2009; Computing at School, 2014; diSessa, 2001; Guzdial, 2008; Hayles, 2012; Jenkins, 2015; Papert, 1996; Park \& Jeon, 2015; Williamson, 2015; Wing, 2006). It could be argued that this fact emphasized the research and investigation-based structures prevalent in different fields (Papert, 1980; Wing, 2006). Moreover, it was observed that CT was less expressed as a thinking instrument, system and process. It was considered that CT should be examined for the elements that illuminate the functional aspects in future studies, and these concepts should be included in the definitions.

It was noteworthy that personal traits were less emphasized in CT, which was based on problem solving by individuals. Under the topic of personal traits, concepts such as individual skills, cognitive factors and perspective were included (DeSchryver \& Yadav, 2015; diSessa, 2001; Furber, 2012; Jacobson \& Wilensky, 2006; Kafai \& Burke, 2014; Lu \& Fletscher, 2009; Park \& Jeon, 2015; Snapp \& Neumann, 2015) and specifications on personal traits were limited. It was considered that this was due to the fact that CT is a novel topic that requires further studies. Considering that individual differences such as communication skills, academic achievement, intelligence, age, gender, culture, psychological factors and socio-economic status are effective factors on thinking and learning processes (Jarvis, 2005; Jonassen \& Grabowski, 2011; Sharma \& Sharma, 2006; Toth, 2014; Tuckman \& Monetti, 2011; Woolfolk \& Margetts, 2013), comprehensive examination of personal traits within the context of CT and its inclusion in the definitions in future studies would improve the comprehension of the concept.

Statements on the functional properties of $\mathrm{CT}$ that include the dimensions of operational quality, design, assessment and production of new information were very limited. It could be argued that the lack of the mention of the abovementioned concepts related to CT, which is considered as a 21st Century skill (Sanford, 2013), was a 
gap in the literature. Moreover, it could be stated that the ambiguities in the assessment dimension of CT in the literature (Haseski, İlic, \& Tuğtekin, 2017) indicated the abovementioned gap. Further research on the subject that would investigate the dimensions of assessment, production of new information and design in CT and the resulting definitions of the concept would lead to an in-depth comprehension of CT.

The specifications on the general qualities of CT were consistent with Özçınar's specifications (2017) and indicated that the topic was popular, appealed to a wide range of fields and was applicable in different disciplines (Brennan \& Resnick, 2012; Carnegie Mellon, 2014; Chang, 2014; DeSchryver \& Yadav, 2015; Evia, Sharp, \& Pérez-Quiñones, 2015; Jacobson \& Wilensky, 2006; National Research Council, 2010; Wing, 2008). On the other hand, it can be said that the low number of specifications in the said topic were relatively inadequate in explaining CT. It was considered that future studies should be conducted on the improvement of the prevalence of $\mathrm{CT}$ in the public at large and its use in a wide variety of disciplines, and further definitions should include specifications that emerge as a result of the future findings, consistent with the present gap in the literature.

It was considered that the social specifications included in the definitions were highly inadequate considering that CT could be actively used in all areas of life and is a skill that is relevant to all individuals (Martinez \& Echeveste, 2015; Wing, Henderson, Hazzan, \& Cortina, 2005). Similarly, the lack of specifications in the dimensions of ethics, the impact of environmental factors, collaborative problem solving, benefiting from the experiences of others, creating social values under the social dimension was noteworthy. Conversely, it could be stated that these characteristics were not adequately emphasized in CT definitions, considering that humankind is a social being who exists within the society and could make conscientious decisions (Cooley, 1992; Dewey, 2002; Hume, 2012). Thus, it was considered that further studies should be conducted to examine the share of abovementioned factors in $\mathrm{CT}$ and these factors should be included in future definitions.

When examined from the perspective of trends, the fact that problem solving specifications were prominent in definitions published before 2006 was parallel to the specifications that CT was based on problem-solving (Wing, 2011; Yadav et al., 2014). In the post-2006 definitions, researchers started to discuss the topic with a broader perspective, including different dimensions. This was consistent with the view that $\mathrm{CT}$ has a multi-dimensional structure (Brennan \& Resnick, 2012a; diSessa, 2001). In particular, it could be argued that the introduction of the emphasis on technology between 2006 and 2010 was due to the impact of ICT on thinking and problem-solving processes. After 2011, the definitions diversified along with the increase in published papers, contributing to the comprehension of the topic. In the said process, it was observed that in time, CT was addressed within the context of an increasing number of dimensions.

It was determined that although the current $\mathrm{CT}$ is shaped by technology-aided problem solving, different dimensions that are effective in the process were introduced over time. On the other hand, the limitations in the definitions demonstrated that there were further dimensions that needed to be exposed and explored. Further studies are required to improve the comprehension of $\mathrm{CT}$, which addresses the set of complex behavior of humankind such as problem-solving, and ensure that $\mathrm{CT}$ is a skill which could be used by all, and to fulfill the abovementioned claim of CT. Thus, further studies that would examine and define CT based on personal, environmental, social, affective, psychological and ethical factors in a multidimensional environment and beyond the present situation would improve its common impact on general public and practical use among the society. Thus, based on findings of the reviewed papers, new methods and techniques for integrating CT into curriculum could be developed and the acquisition of CT skill could be more facile and effective for students from pre-school to university. Furthermore, several activities could be developed in public education for individuals of different ages that could encourage them to improve CT skills and teach these individuals to solve problems in a systematic manner. Thus, further studies would help transform today's society into a computational society and define the future developments on the topic and increase its present significance.

\section{References}

Aho, A. V. (2012). Computation and computational thinking. The Computer Journal, 55(7), 832-835. https://doi.org/10.1093/comjnl/bxs074

Akbulut, Y., \& Cardak, C. S. (2012). Adaptive educational hypermedia accommodating learning styles: A content analysis of publications from 2000 to 2011. Computers \& Education, 58(2), 835-842. https://doi.org/10.1016/j.compedu.2011.10.008

Angeli, C., Voogt, J., Fluck, A., Webb, M., Cox, M., Malyn-Smith, J., \& Zagami, J. (2016). A K-6 computational thinking curriculum framework: Implications for teacher knowledge. Educational Technology \& Society, 19(3), 47-57. 
Barr, D., Harrison, J., \& Conery, L. (2011). Computational thinking: A digital age skill for everyone. Learning \& Leading with Technology, 38(6), 20-23.

Barr, V., \& Stephenson, C. (2011). Bringing computational thinking to K-12: What is involved and what is the role of the computer science education community? ACM Inroads, 2(1), 48-54. http://doi.org/10.1145/1929887.1929905

Basawapatna, A., Koh, K. H., Repenning, A., Webb, D. C., \& Marshall, K. S. (2011). Recognizing computational thinking patterns. Proceedings of the 42nd ACM Technical Symposium on Computer Science Education, USA, 245-250. https://doi.org/10.1145/1953163.1953241

Berland, M., \& Wilensky, U. (2015). Comparing virtual and physical robotics environments for supporting complex systems and computational thinking. Journal of Science Education and Technology, 24(5), 628-647. http://doi.org/10.1007/s10956-015-9552-x

Bers, M. U. (2010). The tangibleK robotics program: Applied computational thinking for young children. Early Childhood Research \& Practice, 12(2), n2.

Brennan, K., \& Resnick, M. (2012). New frameworks for studying and assessing the development of computational thinking. Proceedings of the 2012 Annual of the American Educational Research Association meeting, Canada, 1-25.

Brennan, K., \& Resnick, M. (2012). Using artifact-based interviews to study the development of computational thinking in interactive media design. Proceedings of the Annual American Educational Research Association Meeting. Vancouver, Canada.

Bundy, A. (2007). Computational thinking is pervasive. Journal of Scientific and Practical Computing, 1(2), 67-69.

Carnegie Mellon. (2014). Carnegie Mellon center for computational thinking. Retrieved December 11, 2016, from http://www.cs.cmu.edu/ CompThink/

Chang, C. K. (2014). Effects of using Alice and Scratch in an introductory programming course for corrective instruction. J. Educational Computing Research, 51(2), 185-204. http://doi.org/10.2190/EC.51.2.c

Chen, X. (2009). Students who study science, technology, engineering, and mathematics (STEM) in postsecondary education (NCES 2009-161). Washington: National Center for Educational Statistics.

Computing at School (2014). Computing in the national curriculum: A guide for secondary teachers. Retrieved December 11, 2016, from http://www.computingat school.org.uk/data/uploads/cas_secondary.pdf

Cooley, C. H. (1992). Human nature and the social order. NY: Transaction Publishers.

CSTA. (2011). K-12 computer science standards. Retrieved December 11, 2016, from http://csta.acm.org/Curriculum/ sub/K12Standards.html

Demir, Ö., \& Seferoğlu, S. S. (2017). Yeni kavramlar, farklı kullanımlar: Bilgi-işlemsel düşünmeyle ilgili bir değerlendirme [New concepts, different uses: An assessment of computational thinking]. In H. F. Odabaş1, B. Akkoyunlu, \& A. İşman (Eds.), Eğitim teknolojileri okumaları 2017 [Educational technology readings 2017] (pp. 468-483). Sakarya: Sakarya University Press.

Denning, P. J. (2003). Great principles of computing. Communications of the ACM, 46(11), 15-20. http://doi.org/10.1145/948383.948400

Denning, P. J. (2012). Reflections on a symposium on computation. The Computer Journal, 55(7), 799-802. https://doi.org/10.1093/comjnl/bxs064

Denning, P., \& Freeman, P. (2009). Computing's paradigm. Communications of the ACM, 52(12), 28-30. https://doi.org/10.1145/1610252.1610265

DeSchryver, M. D., \& Yadav, A. (2015). Creative and computational thinking in the context of new literacies: Working with teachers to scaffold complex technology-mediated approaches to teaching and learning. Journal of Technology and Teacher Education, 23(3), 411-431.

Dewey, J. (2002). Human nature and conduct. NY: Dover Publications.

diSessa, A. (2001). Changing minds: Computers, learning, and literacy. MA: MIT Press.

Evia, C., Sharp, M. R., \& Pérez-Quinones, M. A. (2015). Teaching structured authoring and DITA through rhetorical and computational thinking. IEEE Transaction on Professional Communication, 58(3), 328-343. 
https://doi.org/10.1109/TPC.2016.2516639

Fraenkel, J. R., \& Wallen, N. (2000). How to design and evaluate research in education (4th ed.). NY: McGraw-Hill.

Furber, S. (2012). Shut down or restart? The way forward for computing in UK schools. UK: The Royal Society.

Goktas, Y., Kucuk, S., Aydemir, M., Telli, E., Arpacik, O., Yildirim, G., \& Reisoglu, I. (2012). Educational technology research trends in Turkey: A content analysis of the 2000-2009 decade. Educational Sciences: Theory and Practice, 12(1), 191-199.

Grover, S., \& Pea, R. (2013). Computational thinking in K-12: A review of the state of the field. Educational Researcher, 42(1), 38-43. https://doi.org/10.3102/0013189X12463051

Guzdial, M. (2008). Education: Paving the way for computational thinking. Communication of the ACM, 51(8), 25-27. https://doi.org/10.1145/1378704.1378713

Haseski, H. İ., İlic, U., \& Tuğtekin, U. (2017). Computational thinking in educational digital games: An assessment tool proposal. In H. Ozcinar, G. Wong, \& H. T. Ozturk (Eds.), Teaching computational thinking in primary education (pp. 256-287). USA: IGI Global Publishing. https://doi.org/10.4018/978-1-5225-3200-2

Hayles, N. K. (2012). How we think: Digital media and contemporary technogenesis. IL: The University of Chicago Press. https://doi.org/10.7208/chicago/9780226321370.001.0001

Hume, D. (2012). A treatise of human nature. NY: Dover Publications.

Israel, M., Jamie N., Pearson, T. T., Wherfel, Q. M., \& Reese, G. (2015). Supporting all learners in school-wide computational thinking: A cross-case qualitative analysis. Computers \& Education, 82, 263-279. https://doi.org/10.1016/j.compedu.2014.11.022

ISTE \& CSTA. (2011). Operational definition of computational thinking for K-12 education. Retrieved December 25, 2016, from http://www.iste.org/docs/ct-documents/computational-thinking-operationaldefinition-flyer.pdf?sfvrs $\mathrm{n}=2$

ISTE (2011). Operational definition of computational thinking for $K-12$ education. Retrieved from http://www.iste.org/docs/ct-documents/computational-thinking-operational-definition-flyer.pdf?sfvrsn=2

Jacobson, M., \& Wilensky, U. (2006). Complex systems in education: Scientific and educational importance and implications for the learning sciences. $J$ Learn Sci, 15(1), 11-34. https://doi.org/10.1207/s15327809j1s1501_4

Jarvis, M. (2005). The psychology of effective learning and teaching. UK: Nelson Thornes.

Jenkins, C. (2015). Poem generator: A comparative quantitative evaluation of a microworlds based learning approach for teaching English. International Journal of Education and Development Using Information and Communication Technology (IJEDICT), 11(2), 153-167.

Jonassen, D. H., \& Grabowski, B. L. (2011). Handbook of individual differences, learning and instruction. NY: Routledge.

Kafai, Y. B. (2016). Education from computational thinking to computational participation in K-12 education seeking to reframe computational thinking as computational participation. Communications of the ACM, 59(8). https://doi.org/10.1145/2955114

Kafai, Y. B., \& Burke, Q. (2013). Computer programming goes back to school: Learning programming introduces students to solving problems, designing applications, and making connections online. Kappan, 95(1), 61-65. https://doi.org/10.1177/003172171309500111

Kafai, Y. B., \& Burke, Q. (2014). Connected code: Why children need to learn programming. Cambridge, MA: MIT Press.

Kilpeläinen, P. (2010). Do all roads lead to Rome or reductions for dummy travelers. Computer Science Education, 20(3), 181-199. https://doi.org/10.1080/08993408.2010.501226

Kim, B., Kim, T., \& Kim, J. (2013). Paper-and-pencil programming strategy toward computational thinking for non-majors: Design your solution. Journal of Educational Computing Research, 49(4), 437-459. https://doi.org/10.2190/EC.49.4.b

Kim, S., Han, S., \& Kim, H. (2009). How can we teach computational literacy to all levels of students? 5th 
International Joint Conference on INC, IMS and IDC, Seoul, 1395-1400. https://doi.org/10.1109/NCM.2009.192

Kirk, J., \& Miller, M. L. (1986). Reliability and validity in qualitative research. USA: Sage. https://doi.org/10.4135/9781412985659

Kostadinov, B. (2013). Simulation insights using R. PRIMUS, 23(3), 208-223. https://doi.org/10.1080/10511970.2012.718729

Kucuk, S., Aydemir, M., Yildirim, G., Arpacik, O., \& Goktas, Y. (2013). Educational technology research trends in Turkey from 1990 to 2011. Computers \& Education, 68, 42-50. https://doi.org/10.1016/j.compedu.2013.04.016

Landis, J. R., \& Koch, G. G. (1977). The measurement of observer agreement for categorical data. Biometrics, 33, 159-174. https://doi.org/10.2307/2529310

Lee, I., Martin, F., Denner, J., Coulter, B., Allan, W., Erickson, J., \& Werner, L. (2011). Computational thinking for youth in practice. ACM Inroads, 2(1), 32-37. https://doi.org/10.1145/1929887.1929902

Lomax, R. G., \& Hahs-Vaughn, D. L. (2012). An introduction to statistical concepts (3rd ed.). NY: Taylor and Francis Group.

Lu, J. J., \& Fletscher, G. H. L. (2009). Thinking about computational thinking. ACM SIGCSE Bulletin, 4l(1), 260-264. https://doi.org/10.1145/1539024.1508959

Martinez, M. C., \& Echeveste, M. E. (2015). Primary and secondary school students' representation about computer sciences and their job. RED-Revista De Educacion A Distancia, (46).

Merriam, S. B., \& Tisdell, E. J. (2015). Qualitative research: A guide to design and implementation. USA: John Wiley \& Sons. https://doi.org/10.4018/978-1-4666-7409-7.ch007

Miller, C. S., \& Settle, A. (2011). When practice doesn't make perfect: Effects of task goals on learning computing concepts. ACM Transactions on Computing Education (TOCE), 11(4), 1-16. https://doi.org/10.1145/2048931.2048933

NAACE (2014). Computing in the national curriculum. Retrieved December 11, 2016, from http://www.computingatschool.org.uk/data/uploads/cas_secondary.pdf

National Research Council. (2008). Taking science to school: Learning and teaching science in grades K-8. Washington: National Academy Press.

National Research Council. (2010). Report of a workshop on the scope and nature of computational thinking. Washington: The National Academies Press.

National Research Council. (2012). A framework for K-12 science education: Practices, crosscutting concepts, and core ideas. Washington: National Academies Press.

Özçınar, H. (2017). Bibliometric analysis of computational thinking. Educational Technology Theory \& Practice, $7(2), 149-171$.

Papert, S. (1980). Mindstorms: Children, computers, and powerful ideas. NY: Basic Books Inc.

Papert, S. (1996). An exploration in the space of mathematics educations. Int J Comput Math Learn, 1(1), 138-142. https://doi.org/10.1007/BF00191473

Park, S. Y., \& Jeon, Y. (2015). Teachers' perception on computational thinking in science practices. International Journal of Education and Information Technologies, 9, 180-185.

Pellas, N., \& Peroutseas, E. (2016). Gaming in Second Life via Scratch4SL: Engaging high school students in programming courses. Journal of Educational Computing Research, 54(1), 108-143. https://doi.org/10.1177/0735633115612785

Sanford, J. F. (2013). Core concepts of computational thinking. International Journal of Teaching and Case Studies, 4(1), 1-12. https://doi.org/10.1504/IJTCS.2013.053383

Selby, C. C. (2014). How can the teaching of programming be used to enhance computational thinking skills? (Doctoral dissertation). University of Southampton, UK.

Selby, C., \& Woollard, J. (2014). Refining an understanding of computational thinking. Author's Original, 1-23.

Sengupta, P., Kinnebrew, J. S., Basu, S., Biswas, G., \& Clark, D. (2013). Integrating computational thinking with K-12 science education using agent-based computation: A theoretical framework. Education and 
Information Technologies, 18, 351-380. https://doi.org/10.1007/s10639-012-9240-x

Sharma, R. N., \& Sharma, R. K. (2006). Advanced educational psychology. New Delhi: Atlantic.

Shih, M. L., Feng, J., \& Tsai, C. C. (2008). Research and trends in the field of e-learning from 2001 to 2005: A content analysis of cognitive studies in selected journals. Computers \& Education, 51(2), 955-967. https://doi.org/10.1016/j.compedu.2007.10.004

Snapp, R. R., \& Neumann, M. D. (2015). An amazing algorithm. Mathematics Teaching in the Middle School, 20(9), 540-547. https://doi.org/10.5951/mathteacmiddscho.20.9.0540

Sneider, C., Stephenson, C., Schafer, B., \& Flick, L. (2014). Computational high school science classrooms. The Science Teacher, 81(5), 53-59. https://doi.org/10.2505/4/tst14_081_05_53

Sullivan, F. R., \& Heffernan, J. (2016). Robotic construction kits as computational manipulatives for learning in the STEM disciplines. Journal of Research on Technology in Education, 48(2), 105-128. https://doi.org/10.1080/15391523.2016.1146563

Toth, P. (2014). The role of individual differences in learning. Acta Polytechnica Hungarica, 11(4), 183-197.

Tuckman, B. W., \& Monetti, D. M. (2011). Educational psychology. CA: Wadsworth.

Van der Kleij, F. M., Feskens, R. C., \& Eggen, T. J. (2015). Effects of feedback in a computer-based learning environment on students' learning outcomes: A meta-analysis. Review of Educational Research, 85(4), 475-511. https://doi.org/10.3102/0034654314564881

Viera, A. J., \& Garrett, J. M. (2005). Understanding interobserver agreement: The kappa statistic. Family Medicine, 37(5), 360-363.

Voogt, J., Fisser, P., Good, J., Mishra, P., \& Yadav, A. (2015). Computational thinking in compulsory education: Towards an agenda for research and practice. Education and Information Technologies, 20(4), 715-728. https://doi.org/10.1007/s10639-015-9412-6

Weber, R. P. (1990). Basic content analysis (2nd ed.). CA: Sage. https://doi.org/10.4135/9781412983488

Whitman, L. E., \& Witherspoon, T. L. (2003). Using LEGOs to interest high school students and improve K12 STEM education. Proceedings of the 33rd Annual Frontiers in Education Conference (ASEE/IEEE), USA, F3A6-F3A10.

Wilensky, U., \& Reisman, K. (2006). Thinking like a wolf, a sheep or a firefly: Learning biology through constructing and testing computational theories-An embodied modeling approach. Cognition and Instruction, 24(2), 171-209. https://doi.org/10.1207/s1532690xci2402_1

Williamson, B. (2015). Governing methods: Policy innovation labs, design and data science in the digital governance of education. Journal of Educational Administration and History, 47(3), 251-271. https://doi.org/10.1080/00220620.2015.1038693

Williamson, B. (2016). Political computational thinking: Policy networks, digital governance and 'learning to code', Critical Policy Studies, 10(1), 39-58. https://doi.org/10.1080/19460171.2015.1052003

Wing, J. (2011). Research notebook: Computational thinking-What and why? Retrieved December 11, 2016, from http://www.cs.cmu.edu/link/research-notebook-computational-thinking-what-and-why

Wing, J. M. (2006). Viewpoint: Computational thinking. Communications of the ACM, 46(3), 33-35. https://doi.org/10.1145/1118178.1118215

Wing, J. M. (2008). Computational thinking and thinking about computing. Philosophical Transactions of the Royal Society A Mathematical, Physical, and Engineering Sciences, 366(1881), 3717-3725. http://doi.org/10.1098/rsta.2008.0118

Wing, J., Henderson, P., Hazzan, O., \& Cortina, T. (2005). Computational thinking. Retrieved December 11, 2016, from http://www.cs.cmu.edu/afs/cs/usr/wing/www/ ct-paper.pdf

Wolz, U., Stone, M., Pearson, K., Pulimood, S. M., \& Switzer, M. (2011). Computational thinking and expository writing in the middle school. ACM Transactions on Computing Education, 11(2), 1-22. https://doi.org/10.1145/1993069.1993073

Woolfolk, A., \& Margetts, K. (2013). Educational psychology (3rd ed.). Australia: Pearson.

Yadav, A., Mayfield, C., Zhou, N., Hambrusch, S., \& Korb, J. T. (2014). Computational thinking in elementary and secondary teacher education. ACM Transactions on Computing Education, 14(1), Article 5. 
https://doi.org/10.1145/2576872

\section{Copyrights}

Copyright for this article is retained by the author(s), with first publication rights granted to the journal.

This is an open-access article distributed under the terms and conditions of the Creative Commons Attribution license (http://creativecommons.org/licenses/by/4.0/). 